\title{
Quantitative assessment of pre-miR-218 rs I I 34527 polymorphism and cancer risk in Chinese population
}

This article was published in the following Dove Press journal:

OncoTargets and Therapy

24 July 2015

Number of times this article has been viewed

\author{
Hongyu Zhao',* \\ Rui Wang ${ }^{2, *}$ \\ 'Central Laboratory, The Second \\ Affiliated Hospital of Southeast \\ University, Nanjing, People's Republic \\ of China; ${ }^{2}$ Nanjing Kingmed Clinical \\ Laboratory Co., Ltd, Nanjing, People's \\ Republic of China \\ *These authors contributed equally \\ to this work
}

Background: Accumulated studies have evaluated the association of pre-miR-218 rs 11134527 polymorphism with cancer risk in Chinese population. However, the results remain controversial.

Methods: To derive a more precise and more comprehensive estimation of the relationship, six studies focused on Chinese population were included for the pooled analysis for pre-miR-218 rs 11134527 polymorphism using odds ratios (ORs) with 95\% confidence intervals (CIs).

Results: Pre-miR-218 rs11134527 polymorphism was associated with cancer risk ( $G$ versus A, OR $=0.93,95 \%$ CI: $0.88-0.98$; GG versus $A G+$ AA, OR $=0.88,95 \%$ CI: $0.79-0.97$; GG versus $\mathrm{AA}, \mathrm{OR}=0.85,95 \% \mathrm{CI}: 0.76-0.96$ ). In the stratified analysis by cancer type, the pre-miR-218 rs 11134527 polymorphism was only associated with the risk of cervical cancer (G versus A, $\mathrm{OR}=0.90,95 \% \mathrm{CI}: 0.83-0.98$; GG versus $\mathrm{AG}+\mathrm{AA}, \mathrm{OR}=0.80,95 \% \mathrm{CI}: 0.68-0.94$; GG versus AA, OR $=0.79,95 \%$ CI: 0.66-0.94).

Conclusion: These findings suggest that the pre-miR-218 rs11134527 genetic polymorphism may decrease the susceptibility to cervical cancer, which needs to be verified or linked with functional studies.

Keywords: single-nucleotide polymorphisms, meta-analysis, polymorphism, cancer, risk

\section{Introduction}

MicroRNAs (miRNAs) are a highly conserved family of small, noncoding RNA species. In mammals, mature miRNAs are generated from primary miRNAs (primiRNAs) and precursor miRNAs (pre-miRNAs) via sequential processing by Drosha and Dicer and negatively regulate the expression of tumor suppressor genes and oncogenes via RNA interference. Therefore, miRNAs play an important role in various biological processes, including cell differentiation, proliferation, apoptosis, and metastasis. ${ }^{1,2}$ Recently, several studies have shown that miR-218 is downregulated in various types of cancer, including glioma, bladder cancer, lung cancer, and oral cancer. $^{3-6}$ The overexpression of miR-218 in cancer cells markedly suppresses invasion and proliferation and promotes apoptosis. ${ }^{6-8}$

Single-nucleotide polymorphism (SNP) is the most abundant form of DNA variation in the human genome. Common polymorphisms in miRNA genes, including pri-miRNAs, pre-miRNAs, and mature miRNAs, may alter various biological processes by influencing the processing and/or target selection of miRNAs. ${ }^{9}$ A potential functional SNP ( $r$ 11134527, A > G) of the putative promoter region of pre-miR-218 has been identified, and many studies from People's Republic of China have explored the association between rs11134527 polymorphism and susceptibility
Correspondence: Hongyu Zhao

Central Laboratory, The Second Affiliated Hospital of Southeast University, I-I

Zhongfu Street, 210003 Nanjing,

People's Republic of China

Email zhaohy1223@I63.com 
to cancer, including esophageal squamous cell carcinoma, hepatocellular carcinoma, and cervical cancer. ${ }^{10-15}$ However, the results of these observations remain controversial and inconclusive. In the present study, we conducted a metaanalysis to derive a more precise and more comprehensive estimation of the associations.

\section{Materials and methods}

\section{Publication search}

We performed a publication search in the PubMed, Web of Science, and Chinese National Knowledge Infrastructure (CNKI) databases (up to March 27, 2015) with the following search terms: "pre-miR-218" or "rs11134527"; "cancer" or "carcinoma"; "genetic variation" or "polymorphism". Handsearches were also performed to identify additional articles in the reference lists of included articles not retrieved by initial electronic search. All of the selected studies met the following criteria: 1) case-control study; 2) concerned the association between pre-miR-218 rs11134527 polymorphism and cancer risk in Chinese population; and 3) available genotype frequency.

\section{Data extraction and quality assessment}

Information was carefully reviewed and independently extracted from all the eligible articles by two investigators. The following items were collected: first author's name, year of publication, country of origin, genotyping method, source of the control groups (population- or hospital-based), total number of cases and controls, genotype distributions in the cases and controls, and $P$-value for Hardy-Weinberg equilibrium (HWE). If discrepancies and differences existed after data collection, discussion was carried out to get consensus.

\section{Statistical analysis}

HWE in the controls was measured via chi-square test. The recessive model ( $\mathrm{GG}$ versus $\mathrm{GA}+\mathrm{AA}$ ), dominant model $(\mathrm{GG}+\mathrm{GA}$ versus AA), codominant model (GG versus AA, GA versus AA), and allelic model (G versus A) were used to assess the association between pre-miR-218 rs11134527 polymorphism and cancer risk in Chinese population. The strength of the association between the pre-miR-218 rs11134527 polymorphism and cancer risk in Chinese population was assessed using odds ratios (ORs) and 95\% confidence intervals (CIs). The significance of the pooled OR was determined using the $z$-test and $P_{z}<0.05$ was considered statistically significant. Chi-square-based $Q$ statistic and $I^{2}$ statistic were conducted to evaluate heterogeneity between studies. If $P_{\mathrm{Q}}<0.05$ or $I^{2}>50 \%$, the random-effects model was used to calculate the pooled OR. Otherwise, the fixed-effects model was selected. In order to evaluate the influence of each study on the overall estimate, we carried out sensitivity analysis by sequentially removing individual studies. Finally, the potential publication bias was tested by funnel plot. All analyses were performed in RevMan 5.0 software. All the tests were two-sided, and the significance level was less than 0.05 .

\section{Results}

\section{Study selection and characteristics}

Through the systematic literature search, six eligible studies containing 11,024 subjects $(5,376$ cancers cases and 5,648 controls) on the association between pre-miR-218 rs 11134527 polymorphism and cancer risk in Chinese population are included in the present meta-analysis. The characteristics of each case-control study are summarized in Table 1. There were two case-control studies of esophageal

Table I General characteristics of studies included in the meta-analysis

\begin{tabular}{|c|c|c|c|c|c|c|c|c|c|c|c|c|c|}
\hline \multirow[t]{2}{*}{ Authors } & \multirow[t]{2}{*}{ Year } & \multirow[t]{2}{*}{ Country } & \multirow{2}{*}{$\begin{array}{l}\text { Cancer } \\
\text { type }\end{array}$} & \multirow{2}{*}{$\begin{array}{l}\text { Source } \\
\text { of controls }\end{array}$} & \multirow[t]{2}{*}{ Detection } & \multirow{2}{*}{$\begin{array}{l}\text { Sample size } \\
\text { (cases/controls) }\end{array}$} & \multicolumn{3}{|c|}{ Cases } & \multicolumn{3}{|c|}{ Controls } & \multirow[t]{2}{*}{ HWE } \\
\hline & & & & & & & AA & AG & GG & AA & AG & GG & \\
\hline Zhang et $\mathrm{al}^{12}$ & 2014 & $\begin{array}{l}\text { People's Republic } \\
\text { of China }\end{array}$ & ESCC & Population & SNaPshot & I, 109/I,275 & 396 & 529 & 184 & 454 & 630 & 191 & 0.25 \\
\hline Jiang et al ${ }^{10}$ & 2014 & $\begin{array}{l}\text { People's Republic } \\
\text { of China }\end{array}$ & ESCC & Hospital & PCR-LDR & $706 / 745$ & 273 & 344 & 89 & 268 & 348 & 129 & 0.38 \\
\hline Han et al' & 2014 & $\begin{array}{l}\text { People's Republic } \\
\text { of China }\end{array}$ & $\mathrm{HCC}$ & Hospital & qPCR & I,009/I,0। I & 372 & 470 & 167 & 336 & 493 & 182 & 0.96 \\
\hline Shi et $\mathrm{al}^{13}$ & 2013 & $\begin{array}{l}\text { People's Republic } \\
\text { of China }\end{array}$ & $\begin{array}{l}\text { Cervical } \\
\text { cancer }\end{array}$ & Hospital & TaqMan & I,565/I,39। & 588 & 752 & 225 & 512 & 638 & 241 & 0.08 \\
\hline Zhang et $\mathrm{al}^{14}$ & 2012 & $\begin{array}{l}\text { People's Republic } \\
\text { of China }\end{array}$ & $\mathrm{HCC}$ & Hospital & PCR-RFLP & $302 / 513$ & 88 & 170 & 44 & 165 & 269 & 79 & 0.07 \\
\hline Zhou et al ${ }^{15}$ & 2010 & $\begin{array}{l}\text { People's Republic } \\
\text { of China }\end{array}$ & $\begin{array}{l}\text { Cervical } \\
\text { cancer }\end{array}$ & Hospital & PCR-RFLP & $685 / 713$ & 268 & 316 & 101 & 247 & 339 & 127 & 0.57 \\
\hline
\end{tabular}

Abbreviations: ESCC, esophageal squamous cell carcinoma; HCC, hepatocellular carcinoma; HWE, Hardy-Weinberg equilibrium; PCR, polymerase chain reaction; PCR-LDR, PCR-ligase detection reaction; PCR-RFLP, PCR-restriction fragment length polymorphism; qPCR, quantitative PCR. 
Table 2 Meta-analysis of the pre-miR-2 I 8 rs I I I 34527 polymorphism and cancer risk among Chinese population

\begin{tabular}{|c|c|c|c|c|c|c|c|c|c|c|c|c|}
\hline \multirow[t]{2}{*}{ Variables } & \multicolumn{4}{|c|}{ Allelic model (G versus A) } & \multicolumn{4}{|c|}{$\begin{array}{l}\text { Dominant model } \\
\text { (GG + GA versus AA) }\end{array}$} & \multicolumn{4}{|c|}{$\begin{array}{l}\text { Recessive model } \\
\text { (GG versus AG + AA) }\end{array}$} \\
\hline & $I^{2}$ & $\boldsymbol{P}_{\text {het }}$ & $P_{z}$ & OR $(95 \% \mathrm{CI})$ & $P^{2}$ & $\boldsymbol{P}_{\text {het }}$ & $P_{z}$ & OR $(95 \% \mathrm{CI})$ & $I^{2}$ & $\boldsymbol{P}_{\text {het }}$ & $P_{z}$ & OR $(95 \% \mathrm{Cl})$ \\
\hline All & $29 \%$ & 0.22 & 0.01 & $0.93(0.88-0.98)$ & $0 \%$ & 0.42 & 0.08 & $0.93(0.86-1.01)$ & $45 \%$ & 0.11 & 0.01 & $0.88(0.79-0.97)$ \\
\hline \multicolumn{13}{|l|}{ Cancer type } \\
\hline ESCC & $73 \%$ & 0.05 & 0.55 & $0.95(0.79-1.14)$ & $0 \%$ & 0.42 & 0.49 & $0.95(0.84-1.09)$ & $86 \%$ & $<0.01$ & 0.64 & $0.89(0.55-1.44)$ \\
\hline Cervical cancer & $0 \%$ & 0.39 & 0.02 & $0.90(0.83-0.98)$ & $29 \%$ & 0.23 & 0.18 & $0.92(0.8 \mathrm{I}-1.04)$ & $0 \%$ & 0.98 & $<0.01$ & $0.80(0.68-0.94)$ \\
\hline \multirow[t]{2}{*}{$\mathrm{HCC}$} & $34 \%$ & 0.22 & 0.24 & $0.94(0.84-1.04)$ & $63 \%$ & 0.10 & 0.81 & $0.97(0.72-1.29)$ & $0 \%$ & 0.88 & 0.36 & $0.9 \mathrm{I}(0.75-\mathrm{I} . \mathrm{II})$ \\
\hline & \multicolumn{4}{|c|}{ Codominant model (GG versus AA) } & \multicolumn{8}{|c|}{ Codominant model (GA versus AA) } \\
\hline All & $39 \%$ & 0.14 & $<0.01$ & $0.85(0.76-0.96)$ & $0 \%$ & 0.49 & 0.34 & $0.96(0.88-1.04)$ & & & & \\
\hline \multicolumn{13}{|l|}{ Cancer type } \\
\hline ESCC & $83 \%$ & 0.02 & 0.58 & $0.87(0.54-1.4 I)$ & $0 \%$ & 0.96 & 0.62 & $0.97(0.84-1.11)$ & & & & \\
\hline Cervical cancer & $0 \%$ & 0.59 & $<0.01$ & $0.79(0.66-0.94)$ & $35 \%$ & 0.21 & 0.64 & $0.97(0.85-1.10)$ & & & & \\
\hline $\mathrm{HCC}$ & $0 \%$ & 0.38 & 0.25 & $0.88(0.70-1.10)$ & $64 \%$ & 0.10 & 0.91 & $0.98(0.72-1.34)$ & & & & \\
\hline
\end{tabular}

Abbreviations: $\mathrm{Cl}$, confidence interval; ESCC, esophageal squamous cell carcinoma; HCC, hepatocellular carcinoma; OR, odds ratio; het, heterogeneity.

squamous cell carcinoma, two of hepatocellular carcinoma, and two of cervical cancer. The genotype frequencies for the control group were all consistent with HWE in the included studies.

\section{The pooled analysis}

The main results of pooled ORs for pre-miR-218 rs 11134527 polymorphism and cancer risk in Chinese population are listed in Table 2. Overall, the pooled OR showed significant associations under the allelic model ( $G$ versus $A$, $\mathrm{OR}=0.93,95 \%$ CI: $0.88-0.98$ ), recessive model (GG versus $\mathrm{AG}+\mathrm{AA}, \mathrm{OR}=0.88,95 \% \mathrm{CI}: 0.79-0.97)$, and codominant model (GG versus AA, OR $=0.85,95 \%$ CI: 0.76-0.96) (Figure 1). In the stratified analysis by cancer type, the premiR-218 rs11134527 polymorphism was only associated with the risk of cervical cancer $(\mathrm{G}$ versus $\mathrm{A}, \mathrm{OR}=0.90$, 95\% CI: 0.83-0.98; GG versus $\mathrm{AG}+\mathrm{AA}, \mathrm{OR}=0.80$, 95\% CI: 0.68-0.94; GG versus AA, OR $=0.79,95 \%$ CI: 0.66-0.94).

\section{Sensitivity analysis and publication bias}

Sensitivity analysis was performed to evaluate the stability of the results by removing one study at a time. We found that the estimated pooled ORs changed quite little, indicating that our results were statistically robust. Funnel plots were used to assess publication bias. As shown in Figure 2, the shapes of the funnel plots seemed symmetrical, suggesting the absence of publication bias.

\section{Discussion}

Genetic testing for cancer susceptibility has become a standard component of clinical practice over the last few years. Increasing evidence suggests that some SNPs play vital roles in the development of cancer. ${ }^{16,17}$ Some studies indicated that a potential functional SNP (rs11134527) in tumorsuppressive miR-218 was associated with the risk of cancer in Chinese population. ${ }^{10,11,13,15}$ In contrast, others showed that miR-218 rs11134527 polymorphism was not associated with cancer risk in Chinese population. ${ }^{12,14}$ Considering that

\begin{tabular}{|c|c|c|c|c|c|c|c|c|c|c|}
\hline \multirow{3}{*}{$\begin{array}{l}\text { Study } \\
\text { Zhou et } a^{15}\end{array}$} & \multicolumn{2}{|c|}{ Experimental } & \multicolumn{2}{|c|}{ Control } & \multirow[t]{2}{*}{ Weight } & \multirow{2}{*}{$\begin{array}{l}\text { Odds ratio } \\
\mathrm{M}-\mathrm{H} \text {, fixed, } 95 \% \mathrm{Cl}\end{array}$} & \multirow{2}{*}{ Year } & \multirow{2}{*}{\multicolumn{3}{|c|}{$\begin{array}{l}\text { Odds ratio } \\
\mathrm{M}-\mathrm{H} \text {, fixed, } 95 \% \mathrm{Cl}\end{array}$}} \\
\hline & Events & Total & Events & Total & & & & & & \\
\hline & 101 & 369 & 127 & 374 & $14.0 \%$ & $0.73(0.54-1.00)$ & 2010 & $\varpi$ & & \\
\hline Zhang et al $^{14}$ & 44 & 132 & 79 & 244 & $5.7 \%$ & $1.04(0.67-1.64)$ & 2012 & $\longrightarrow$ & & \\
\hline Shi et $\mathrm{al}^{13}$ & 225 & 813 & 241 & 753 & $27.7 \%$ & $0.81(0.65-1.01)$ & 2013 & $=$ & & \\
\hline Jiang et $\mathrm{al}^{10}$ & 89 & 362 & 129 & 397 & $14.2 \%$ & $0.68(0.49-0.93)$ & 2014 & - & & \\
\hline Han et al ${ }^{11}$ & 167 & 539 & 182 & 518 & $19.6 \%$ & $0.83(0.64-1.07)$ & 2014 & - & & \\
\hline Zhang et al ${ }^{12}$ & 184 & 580 & 191 & 645 & $18.9 \%$ & $1.10(0.87-1.41)$ & 2014 & & & \\
\hline Total $(95 \% \mathrm{Cl})$ & & 2,795 & & 2,931 & $100 \%$ & $0.85(0.76-0.96)$ & & $\downarrow$ & & \\
\hline Total events & 810 & & 949 & & & & & & & \\
\hline $\begin{array}{l}\text { Heterogeneity: } \lambda \\
\text { Test for overall } \epsilon\end{array}$ & $\begin{array}{l}\chi^{2}=8.26, \\
\text { effect: } Z=\end{array}$ & $\begin{array}{l}f=5(P=c \\
2.75(P=\end{array}$ & $\begin{array}{l}0.14) ; p^{2}=3 \\
0.006)\end{array}$ & $39 \%$ & & & 0.01 & $\begin{array}{c}0.1 \\
\text { Favors } \\
\text { xperimental) }\end{array}$ & $\begin{array}{c}10 \\
\text { Favors } \\
\text { (control) }\end{array}$ & 100 \\
\hline
\end{tabular}

Figure I Forest plot of the association between pre-miR-2 I 8 rs I I I34527 polymorphism and cancer risk under GG versus AA. Abbreviations: $\mathrm{Cl}$, confidence interval; $\mathrm{M}-\mathrm{H}$, Mantel-Haenszel test. 


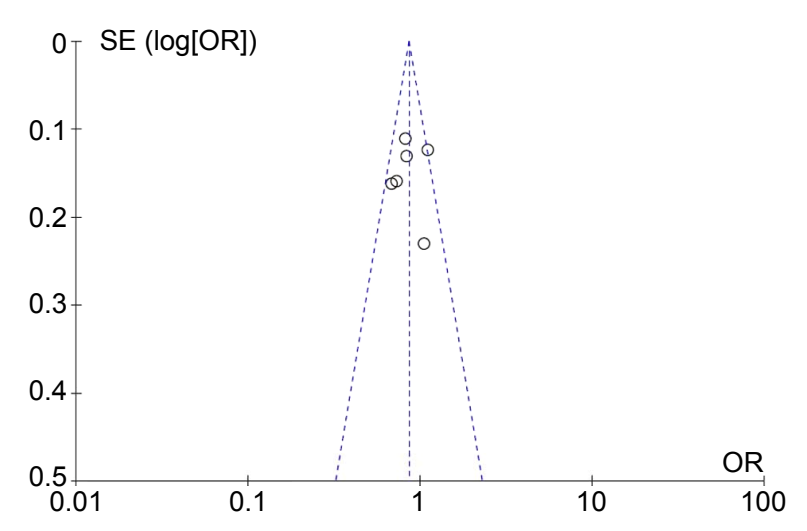

Figure 2 Funnel plot of the association between pre-miR-2। 8 rs III34527 polymorphism and cancer risk under $G G$ versus $A A$.

Abbreviations: OR, odds ratio; SE, standard error.

previous studies from single centers and with small sample sizes may lack enough statistical power to assess the associations, we performed the meta-analysis with larger sample sizes. Results showed miR-218 rs11134527 polymorphism was associated with cancer risk in Chinese population. Furthermore, the stratified analysis based on cancer type suggested that pre-miR-218 rs11134527 polymorphism was only associated with the risk of cervical cancer.

There were some limitations in the current meta-analysis. First, these results are based on unadjusted estimates due to lack of original data from the eligible studies. In addition, only six studies were included in this meta-analysis. Thus, more studies are needed to identify this association more comprehensively.

\section{Conclusion}

A significant association was found between the miR-218 rs11134527 polymorphism and cervical cancer risk in Chinese population. However, large-scale case-control and population-based studies involving potential gene-gene and gene-environment interactions are warranted to confirm our findings.

\section{Disclosure}

The authors report no conflicts of interest in this work.

\section{References}

1. Kloosterman WP, Plasterk RH. The diverse functions of microRNAs in animal development and disease. Dev Cell. 2006;11:441-450.

2. Esquela-Kerscher A, Slack FJ. Oncomirs - microRNAs with a role in cancer. Nat Rev Cancer. 2006;6:259-269.

3. Uesugi A, Kozaki K, Tsuruta T, et al. The tumor suppressive microRNA miR-218 targets the mTOR component Rictor and inhibits AKT phosphorylation in oral cancer. Cancer Res. 2011;71:5765-5778.

4. Tatarano S, Chiyomaru T, Kawakami K, et al. miR-218 on the genomic loss region of chromosome $4 \mathrm{p} 15.31$ functions as a tumor suppressor in bladder cancer. Int J Oncol. 2011;39:13-21.

5. Wu DW, Cheng YW, Wang J, Chen CY, Lee H. Paxillin predicts survival and relapse in non-small cell lung cancer by microRNA-218 targeting. Cancer Res. 2010;70:10392-10401.

6. Song L, Huang Q, Chen K, et al. miR-218 inhibits the invasive ability of glioma cells by direct downregulation of IKK- $\beta$. Biochem Biophys Res Commun. 2010;402:135-140.

7. He X, Dong Y, Wu CW, et al. MicroRNA-218 inhibits cell cycle progression and promotes apoptosis in colon cancer by downregulating BMI1 polycomb ring finger oncogene. Mol Med. 2013;18:1491-1498.

8. Yamamoto N, Kinoshita T, Nohata N, et al. Tumor suppressive microRNA218 inhibits cancer cell migration and invasion by targeting focal adhesion pathways in cervical squamous cell carcinoma. Int J Oncol. 2013;42: 1523-1532.

9. Mishra PJ, Mishra PJ, Banerjee D, Bertino JR. MiRSNPs or MiRpolymorphisms, new players in microRNA mediated regulation of the cell: introducing microRNA pharmacogenomics. Cell Cycle. 2008;7: 853-858.

10. Jiang L, Wang C, Sun C, et al. The impact of pri-miR-218 rs11134527 on the risk and prognosis of patients with esophageal squamous cell carcinoma. Int J Clin Exp Pathol. 2014;7:6206-6212.

11. Han Y, Pu R, Han X, et al. Association of a potential functional pre-miR218 polymorphism and its interaction with hepatitis $\mathrm{B}$ virus mutations with hepatocellular carcinoma risk. Liver Int. 2014;34:728-736.

12. Zhang J, Huang X, Xiao J, et al. Pri-miR-124 rs531564 and pri-miR$34 \mathrm{~b} / \mathrm{c}$ rs 4938723 polymorphisms are associated with decreased risk of esophageal squamous cell carcinoma in Chinese populations. PLoS One. 2014;9:e100055.

13. Shi TY, Chen XJ, Zhu ML, et al. A pri-miR-218 variant and risk of cervical carcinoma in Chinese women. BMC Cancer. 2013;13:19.

14. Zhang LS, Liang WB, Gao LB, et al. Association between pri-miR-218 polymorphism and risk of hepatocellular carcinoma in a Han Chinese population. DNA Cell Biol. 2012;31:761-765.

15. Zhou X, Chen X, Hu L, et al. Polymorphisms involved in the miR-218 LAMB3 pathway and susceptibility of cervical cancer, a case-control study in Chinese women. Gynecol Oncol. 2010;117:287-290.

16. Gao X, Zhang S, Zhu Z. Lysyl oxidase rs 1800449 polymorphism and cancer risk among Asians: evidence from a meta-analysis and a casecontrol study of colorectal cancer. Mol Genet Genomics. 2015;290: 23-28.

17. Gao XR, Zhang SL, Yang YF, Han GR. FEN1 $-69 \mathrm{G}>\mathrm{A}$ and $4150 \mathrm{G}>\mathrm{T}$ polymorphisms and cancer risk in Chinese population. Sci Rep. 2014;4: 6183
OncoTargets and Therapy

\section{Publish your work in this journal}

OncoTargets and Therapy is an international, peer-reviewed, open access journal focusing on the pathological basis of all cancers, potential targets for therapy and treatment protocols employed to improve the management of cancer patients. The journal also focuses on the impact of management programs and new therapeutic agents and protocols on

\section{Dovepress}

patient perspectives such as quality of life, adherence and satisfaction. The manuscript management system is completely online and includes a very quick and fair peer-review system, which is all easy to use. Visit http://www.dovepress.com/testimonials.php to read real quotes from published authors. 